J. Clin. Chem. Clin. Biochem.

Vol. 14, 1976, pp. 151-153

\title{
The ICSH Reference Method for Serum Iron Assay: Recommendation for a Viable Automated Alternative
}

\author{
By $P$. Carter $^{1}$ ) \\ Chemistry Section, Department of Pathology Wilmington Medical Center, Wilmington, Del., 19899 U.S.A.
}

(Received October 23, 1975)

Summary: A viable alternative to the ICSH reference method for serum iron assay is proposed where automated batch analysis is required. The introduction of Ferrozene into contemporary automated methodology makes this possible. The Donnan effect on membrane dialysis has been resolved by observing the fate of aqueous and protein matrices inoculated with ${ }^{59} \mathrm{FeCl}_{3}$ as they leave the system.

\section{Die ICSH-Referenzmethode zur Bestimmung von Eisen im Serum. Empfehlung für eine leistungsfähige automatisierte Alternative}

Zur automatisierten Analyse von Serien wird eine leistungsfähige Alternative zur ICSH-Referenzmethode für die Eisenbestimmung im Serum vorgeschlagen. Sie beruht auf der Einführung von Ferrozin in eine zeitgemäße automatisierte Methodik. Der Donnan-Effekt auf die Membrandialyse wurde bestimmt. Dazu wurde an ${ }^{59} \mathrm{FeCl}_{3}$ markierten, wäßrigen und proteinhaltigen Proben untersucht, wie diese das System verlassen.

\section{Introduction}

In September 1971 in a communication from this laboratory delivered at the First Czechoslovak Congress on Clinical Biochemistry, Prague, we described the application of an inexpensive commercially available ferroin reagent for the analysis of serum iron adapted to the Technicon Autoanalyzer (1). Since that time over 7,000 determinations have been performed by this methodology at the laboratories of the Wilmington Medical Center. A method for serum iron assay which could be used for both reference and routine use was proposed by an Expert Panel on Iron of the International Committee on Standardization in Hemotology (ICSH) in 1971 and since the Committee has recommended requests and comments, this report describes a viable alternative to the ICSH manual method where large numbers of serum specimens must be processed, by incorporating a cheap ferroin ligand in existing automated technology to yield rapid sensitive iron determinations at the microgram level with results in near agreement with the panel's reference method. This follow-up report involves a statistical comparison between the methods together with a tracer experiment devised to further substantiate the role of sodium chlochloride as a compensating electrolyte on the Donnan effect in Autoanalyzer membrane dialysis.

\section{The Modified ICSH Method}

In this laboratory reduction in the severity of contamination error in trace metal analysis is accomplished by performing all reactions with disposable graduated pipets, encompassing a volume between 0.10 and $1.00 \mathrm{ml}$ and by employing disposable polyethylene test tubes simultaneously as reaction vessels and absorption cuvets having a $12 \mathrm{~mm}$ light path adapted to the Coleman $\mathrm{Jr}_{\mathrm{r}}$. spectrophotometer as recently described (2). All aqueous solutions are prepared from water which has been purified by distillation followed by mixed-resin bed deionization. Internal self blanking of individual centrifugates before and after the color reaction precludes any variation in the cuvet optics as well as any slight turbidity error as recently described by Rice \& Fenner (3).

Essentially to $1.0 \mathrm{ml}$ of serum is added $1.0 \mathrm{ml}$ of protein precipitant $(I)$ as described by the panel. To $1.0 \mathrm{ml}$ of the protein free centrifugate is added $1.0 \mathrm{ml}$ of sodium acetatc buffer ( $2 \mathrm{~mol} / 1$ - II) without sulfonate. A "blank" reading is made against water at $535 \mathrm{~nm} ; 0.2 \mathrm{ml}$ of chromogen solution $250 \mathrm{mg} / \mathrm{l}$ sodium bathophenanthroline is added, mixed and the reaction vessel is read again after 5 minutes after the ferrous

1) Presented in part at the second Czechoslovak Congress with international participation on Clinical Biochemistry, Bratislava, September, 1975. 
complex has formed. The metal concentration can be expressed as: $((A u-A b) /(A s-A b)) \times 200$, where $A u, A s$, and $A b$ indicate the net absorbance difference before and after self blanking. Of 87 specimens studied the absorbance of buffered centrifugates is rarely' grcater than 0.015 when read against water.

\section{The Proposed Automated Alternative Using Ferrozene}

The automated Technicon adaptation previously described (1) was specifically designed for incorporation in the popular Babson modified method of Young \& Hicks (4) as well as the method of Giovaniello et al (5). Iron is simultaneously released from protein and reduced by hydrochloric-thioglycolic acid. The reduced iron is separated from protein by dialysis in $1 \mathrm{~mol} / \mathrm{l}$ sodium chloride, eliminating the unfavorable Donnan effect on ferrous ions which otherwise would produce erroneously high values because of accumulated positive charge on the protein. The ferrous dialysate reacts with buffered Ferrozene ${ }^{2}$ ), a monosodium salt of 3-(2-pyridyl)-5, 6- bis-(4-phenylsulfonic acid), at a controlled $\mathrm{pH}$ and is then measured colorimetrically. No specimen screening precedent to analysis is required since the flow rate is sufficient to prevent occasional protein flocculation at the junction of the sample and diluent streams as described in a subsequent report from another laboratory (6).

\section{Comparative Statistical Parameters}

87 serum specimens embracing a concentration span of 4-84 $\mu \mathrm{mol} / 1$ were analyzed in duplicate by the reference ICSH method and the proposed adaptation. Figure 1 is a graphical representation of this data indicating a near identical degree of correlation between the two techniques with no significant difference between pairs of data. There is a bias of $0.500 \mu \mathrm{mol} / 1$ and the standard deviation of the difference is $1.170 \mu \mathrm{mol} / \mathrm{l}$. Only one favorable statistical evaluation of automated technology using sodium bathophenanthroline with the proposed ICSH method has appeared in the literature to date (7), therefore the possibility of employing Ferrozene which is presently marketable at one-tenth the cost of sodium bathophenanthroline in a reaction milieu yielding about $26 \%$ increase in sensitivity (8) should make this adaptation well worth considering.

\section{Fate of ${ }^{59} \mathrm{Fe} \mathrm{Cl}_{3}$ in the Dialysis Module}

The debated role of sodium chloride as an effective compensating electrolyte on the Donnan equilibrium (9) in autoanalyzer membrane dialysis was resolved in the following manner as illustrated in Figure 2.

\footnotetext{
2) Hach Chemical Co., Ames, Iowa, 50010.
}

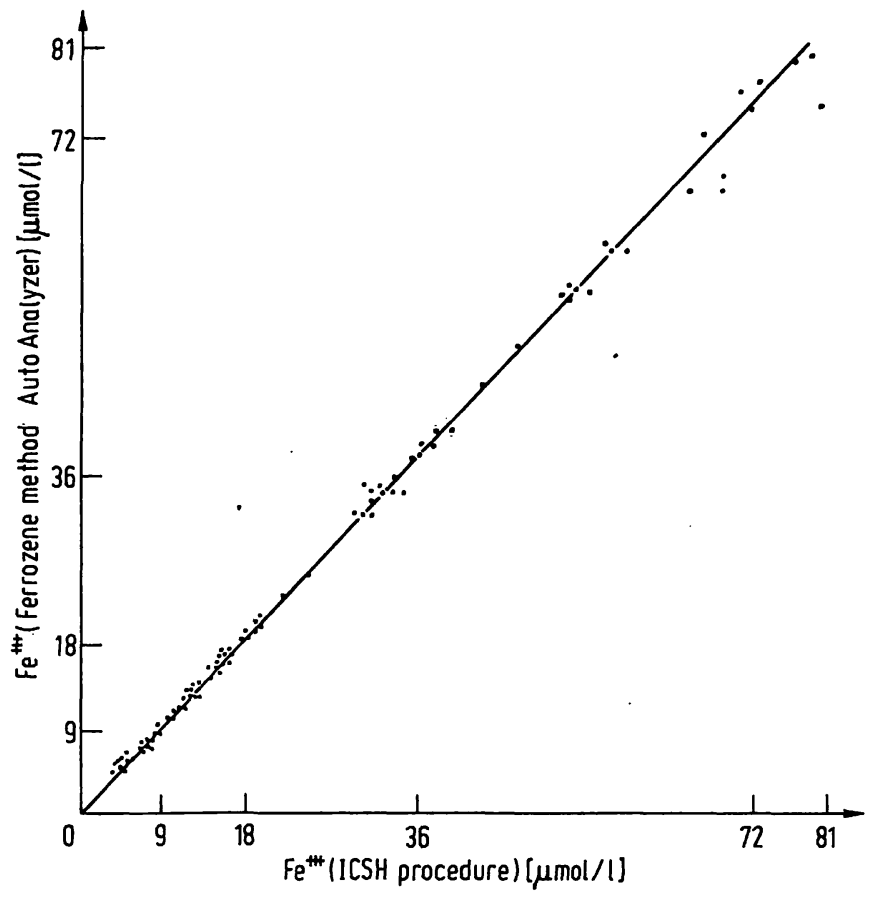

Fig. 1. Comparison of serum iron concentration obtained by the ICSH procedure and the suggested Ferrozene automated method.

Estimating equation

$y=1.01 x+0.016$

$\mathrm{n}=87$

$\mathrm{SD}_{\mathrm{d}}=1.17$

$r=0,999$

$\overline{\mathrm{x}}=23.0$

$\bar{y}=23.5$

"Paired t" $=0.159$

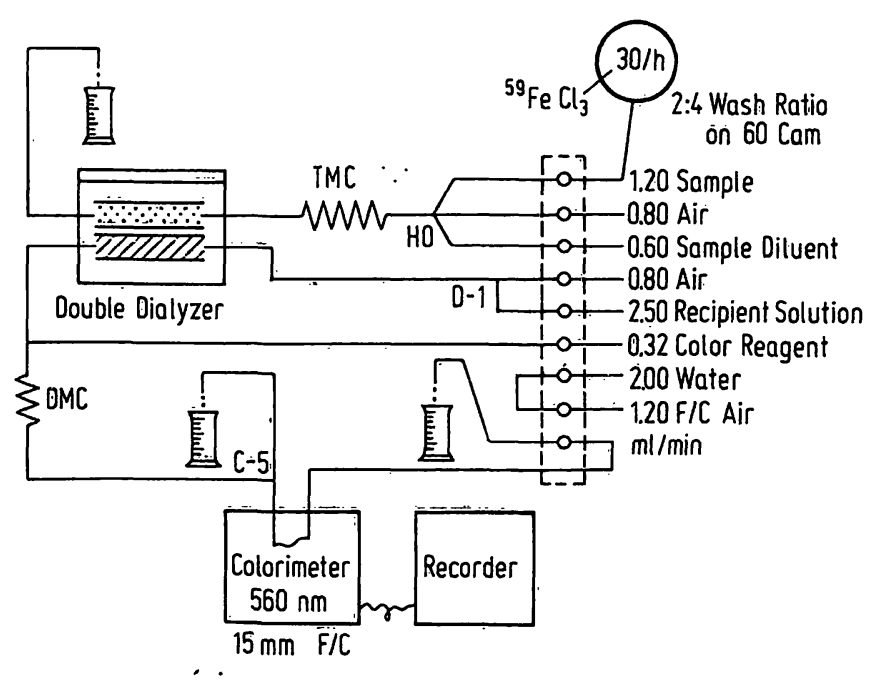

Fig. 2. Diagrammatic schemes for addition and collection of tagged ${ }^{59} \mathrm{FeCl}_{3}$ in automated serum iron analysis.

To $5.0 \mathrm{ml}$ of pooled serum as well as an aqueous standard prepared from $\mathrm{Fe}\left(\mathrm{NH}_{4}\right)_{2} \cdot 6 \mathrm{H}_{2} \mathrm{O}$ was added $200 \mu \mathrm{l}$ of ${ }^{59} \mathrm{FeCl}_{3}$ at a concentration about $25 \mathrm{mCi} / \mathrm{l}$. Specimens were allowed 
to incubate at $37^{\circ} \mathrm{C}$ overnight and were then assayed by the automated method as they passed through the module system. Effluent streams from dialyzer, colorimeter and waste were collected for timed intervals, the volume recorded, and the activity in a predetermined aliquot was measured. Partition variation for dialy sate was determined by dividing the activity from the colorimeter and waste by the total activity emitted from all modules.

Table 1 illustrates the effect of this variation on duplicate aqueous standards and serum specimens when $1 \mathrm{~mol} / \mathrm{l}$ $\mathrm{NaCl}$ is introduced into the diluent stream and when it is omitted: It is evident that $\mathrm{NaCl}$ is an effective agent for equalizing the dialysis rate of ferrous ion from aqueous and serum matrices and that an error of not more than about $2.0 \%$ will be incurred.
Tab. 1. The cffect of electrolyte compensation on membrane dialysis in the presence of ${ }^{59} \mathrm{FeCl}_{3}$.

\begin{tabular}{|c|c|c|c|c|}
\hline & \multicolumn{2}{|c|}{ With $1 \mathrm{~mol} / 1 \mathrm{NaCl}$} & \multicolumn{2}{|c|}{ Without $\mathrm{NaCl}$} \\
\hline & $\begin{array}{l}\text { Serum } \\
\text { Pool }\end{array}$ & $\begin{array}{l}\text { Aqucous } \\
\text { Standard }\end{array}$ & $\begin{array}{l}\text { Serum } \\
\text { Pool }\end{array}$ & $\begin{array}{l}\text { Aqueous } \\
\text { Standard }\end{array}$ \\
\hline $\begin{array}{l}\text { Colorimeter (Counts) } \\
\text { Manifold Waste } \\
\text { (Counts) }\end{array}$ & $\begin{array}{l}37400 \\
61300\end{array}$ & $\begin{array}{l}35400 \\
54600\end{array}$ & $\begin{array}{r}70300 \\
102500\end{array}$ & $\begin{array}{l}60000 \\
85100\end{array}$ \\
\hline $\begin{array}{l}\text { Dialyzer (Counts) } \\
\% \text { Dialyzed } \\
\% \text { Partition Error }\end{array}$ & $\begin{array}{l}182000 \\
34.1 \\
1 .\end{array}$ & $\begin{array}{l}179000 \\
33.5 \\
8 \%\end{array}$ & $\begin{array}{l}288000 \\
37.5 \\
\\
12\end{array}$ & $\begin{array}{l}290000 \\
33.3 \\
6 \%\end{array}$ \\
\hline
\end{tabular}

\section{References}

1. Carter, P. (1972), Mikrochim. Acta, 410-419.

2. Carter, P. (1974), Clin. Chim. Acta., 52, 277-286.

3. Rice, E. W. \& Fenner, H. E. (1974), Clin. Chem. Acta, $53,391-393$

4. Babson, A. L. \& Kleinmann, N. M. (1967), Clin. Chem. 13, $163-166$.

5. Giovanniello, T. J., DiBenedetto, G., Palmer, D. W. \& Peters, Jr., T. (1968), J. Lab. Clin. Med. 71, 874-883.
6. Yee, H. Y. \& Zin, A. (1971), Clin. Chem. 17, 950-953.

7. Brozonic, B. \& Purcell, Y. (1974), J. Clin. Pathol. 27, 222-225.

8. Carter, P. (1971), Anal. Biochem. 40, 450-458.

9. Lestas, A. N. \& Tan, M. P. B. (1972), J. Clin. Pathol. 25, 545-546.
Dr. Paul Carter Chem. Section Wilmington Med. Center Wilmington, Del. 19899 U.S.A. 
